\section{The Oldest Record of a Slug.}

Miss Alice Mackie, writing from Egypt, sends me a photograph showing a couple of slugs represented on a wall at Karnak (Fig. 1). These figures are of course well known to Egyptologists, but probably not to malacologists. They appear to represent the species Veronicella nilotica (Cockerell, Nautilus, January 1910, p. 108), which was found by the Nile above Khartoum. In my original account $I$ could only give the coloration as shown by alcoholic material. Mrs. G. B.

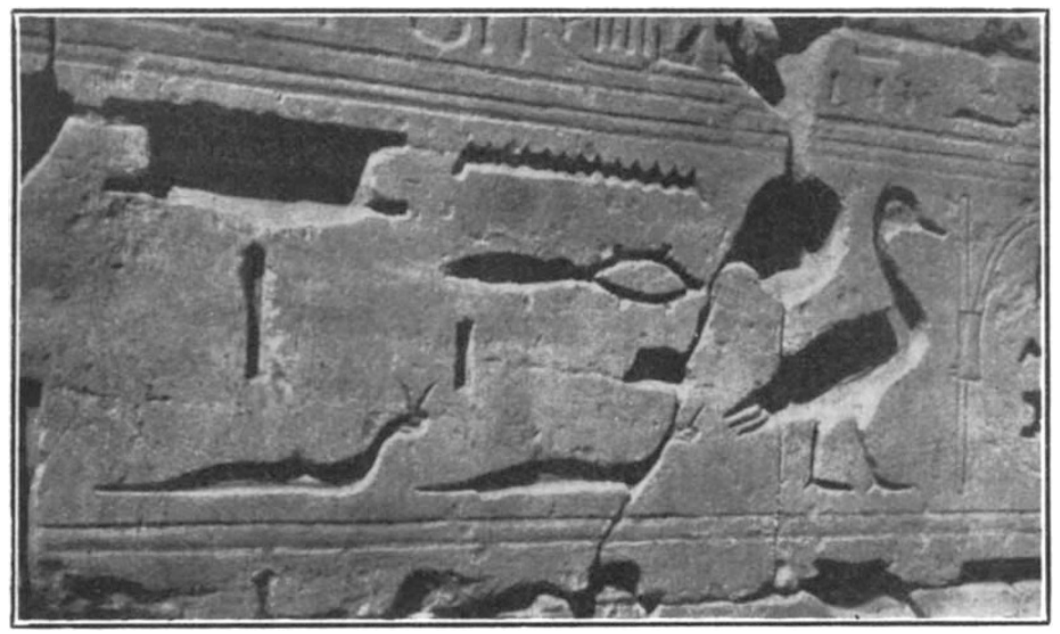

FIG. 1.

Longstaff found a specimen among papyrus on the river bank at Hillet al-Nuwer, an islet on the Bahr el-Gebel. She noted that the living animal was very dark grey above, beneath dirty yellow turning to deeper yellow anteriorly. ${ }^{1}$ This agrees sufficiently with the Luxor figures, which are shown to be dark above and pale below. As this is the only slug of the kind known from this region, the identity is reasonably certain.

T. D. A. Cockerell.

University of Colorado, Boulder, Colorado, Mar. 30

Robson Journal Linnean Soc., Zoology, 32, p. 268, 1914.

\section{Polarisierte und gerichtete Röntgenstrahlung aus einem Kristall.}

DURCH mehrere experimentelle Untersuchungen habe ich festgestellt, dass die Atome der Elemente Wasserstoff und Helium eine ausgezeichnete Achse besitzen, in Bezug auf welche die Gleichgewichtslagen ihrer Elektronen angeordnet sind. Auf Grund spektraler Analogie kann man folgern, dass auch bei den schweren Elementen die Elektronen an der Atomoberfläche in Bezug auf eine ausgezeichnete Achse angeordnet sind.

Analog sind im Innern und auf dem Grunde der Elektronenhülle der schweren Atome die Elektronen in Bezug auf eine ausgezeichnete Achse angeordnet. Dies lasst sich aus einer Erscheinung folgern, welche ich kürzlich aufgefunden habe; es ist die Erscheinung der Polarisation und der gerichteten Intensitatsverteilung der $K$-Strahlung eines Elements aus einem Kristall. Die sekundare $K$-Strahlung des Brom-Atoms, welche infolge der Absorption primärer Rontgenstrahlung von monoklinen $\gamma, \gamma$-Dibromanthrazenkristallen emittiert wird, zeigt nämlich folgende Eigenschaften: in Bezug auf die Achse, welche senkrecht zur Symmetrieebene steht, ist in einer Richtung, welche senkrecht auf dieser Achse steht, die
Intensität der sekundären $K$-Strahlung der Bromatome des Kristalls grösser als in einer Richtung von kleinerem Winkel gegen jene Achse; ausserdem ist diese Strahlung der Bromatome zum Teil in der Weise polarisiert, dass die Intensität der elektrisch parallel jener Achse schwingenden Strahlung bis zu 20 per cent grösser als die Intensität der senkrecht dazu schwing. enden Strahlung ist.

Aus diesen Eigenschaften der $K$-Strahlung der Bromatome aus Dibromanthrazen lassen sich folgende Schlüsse ziehen : 1. die Achsen der chemischen Moleküle in dem Dibromanthrazenkristall liegen parallel zu einanden; 2. die Valenzachsen der Bromatome in diesem Kristall sind einander parallel ; 3. die Elektronen der untersten und der nächsthöheren Schale des Bromatoms, welchen die $K$-Strahlung zugeordnet ist, besitzen in Bezug auf eine ausgezeichnete Achse bestimmte Lagen.

Ein ausführlicher Bericht über die vorstehende Untersuchung wird voraussichtlich in den Annalen der Physik erscheinen.

\section{Grosshesselohe-München,} April 15.

\section{The Ancestry of Man.}

THE theory I have been advancing during the last two years that man is not descended from the apes, but from a primitive common anthropoid stock which gave rise to the apes as well as to our own direct ancestors, has gradually come about from the intensive study of fossil man the world over as well as from our recent and more extended knowledge of the anatomy and the habits of the apes. This new knowledge reveals data entirely unknown to Darwin, and he to-day would be among the first to grasp the new outlook and give it his unbiased consideration. I regret to find that advanced and entirely unauthorised reports of my presidential address before the American Association for the Advancement of Science at Des Moines were interpreted as disloyal to Darwin's theory of the descent of man. More extended knowledge of the data on which the new point of view is founded will cause such criticism to subside, as disloyalty to the main features of Darwin's theory of the descent of man is unthinkable.

It seems that in human palæontology new ideas of time and space, as well as of heredity and of the principles of descent or phylogeny, are compelling us to recast or reconsider all the older ideas to which we fell heir at the close of the nineteenth century. I regret that pressure of other work compels me to postpone the assembling of fresh facts and the meeting of many of the arguments which are now being advanced by several authorities for the older point of view. Like all other questions of descent, the problem of human ancestry can only be settled by fresh palæontological discovery. In view of the fact that anthropoid ape remains are very rare and that primitive human remains are still more rare, we may have to wait for several decades before the fortunate discovery is made. The ancestors of man were the most clever of all animals and, therefore, the first to avoid natural burial and fossilisation. HENRY FAIRFIELD OSBORN.

Osborn Research Rooms,

American Museum of Natural History, April 7. 